\title{
Application of SCL Learning Methods and Student Leadership Behavior: A Correlational Study
}

\author{
Ardia Putra ${ }^{1}$, Rijal Maulana ${ }^{2}$, Nurhasanah ${ }^{3}$, Laras Cynthia Kasih ${ }^{4}$ \\ ${ }^{1}$ Fundamental \& Management of Nursing Department, Faculty of Nursing, Universitas Syiah Kuala, Banda \\ Aceh, Indonesia \\ ${ }^{2}$ Nurse Trainer, Occupational Health and Safety Division, PT. Freeport, Indonesia \\ ${ }^{3}$ Gerontological of Nursing Department, Faculty of Nursing, Universitas Syiah Kuala, Banda Aceh, Indonesia \\ ${ }^{4}$ Medical \& Surgical of Nursing Department, Faculty of Nursing, Universitas Syiah Kuala, Banda Aceh, \\ Indonesia
}

Corresponding Author: Nurhasanah

\begin{abstract}
Background: Competency-Based Curriculum (CBC) is a curriculum that is structured based on the main and supporting competencies used to achieve a competent nursing graduate profile. Leadership is the process of influencing and directing others to be motivated to achieve a goal. This study aimed to determine the relationship between the application of the Student-Centered Learning (SCL) method and the development of student leadership behavior at the Faculty of Nursing, Universitas Syiah Kuala (FON-USK).

Methodology: The type of research used is quantitative by using a cross-sectional study design. The sampling technique used in this study is total sampling with a total sample of 382 respondents. The data was collected using a questionnaire sheet, and the data were analyzed using the Pearson Product Moment correlation method.
\end{abstract}

Results: The results show that there is a relationship for the application of all learning methods on the development of student leadership behavior, with p-value are described: small group discussion method (p-value 0.000) and role-play and simulation method ( $\mathrm{p}$-value 0.018 ).

Conclusion: It is recommended that FON- USK continue developing various innovative SCL learning methods based on the Indonesian National Qualifications Framework to improve leadership abilities and the achievement of nursing graduates who can compete in the national and international world of work.
Keywords: Teacher-Centered Learning; StudentCentered Learning; Learning Methods;

Behavior; Leadership; Student

\section{INTRODUCTION}

Nowadays, university graduates must be designed to become agents of change to build an optimal curriculum oriented to values, knowledge, skills, mental attitudes, and ethics (1). The learning process in higher education has now experienced a shift from the TeacherCentered Learning (TCL) method to the Student-Centered Learning (SCL) method, where ownership of learning is no longer solely centered on the lecturer but students (2).

Students are required to actively construct knowledge so that the emphasis is not only on theory but also on how a job will be done. If this curriculum is implemented, it will not be too difficult for students to change themselves from incompetent to competent graduates with abilities in the form of hard skills and soft skills (2).

Competency-Based Curriculum (CBC) is a formal tool that is very strategic to underlie comprehensive education and learning management in higher education (1). The Faculty of Nursing Universitas Syiah Kuala (FON-USK) has implemented CBC with the SCL method for each block of lectures starting in the 2010/2011 academic year. In CBC, during the implementation of the course, the tutor must provide various assessments of soft skills, one of which is leadership ability. The assessment is carried out on students through various learning activities, including face-to-face tutorial classes, laboratory practice, and field practice (3). 
Leadership can be defined as "... the ability to influence a group toward the achievement of goals" (4). The words "ability," "influence," and "group" are vital concepts in Robbins' definition.

Leadership is one component of soft skills that need to be honed by students. Putra and Pratiwi (5) created a modified acronym from various essential soft skills categorized by Patrick S. O'Brien as seven areas called "Winning Characteristics," namely the acronym COLLEGE, namely: Communication Skills, Organizational Skills, Leadership, Logic, Effort, Group Skills, and Ethics. Moreover, this leadership can be formed from various activities and behaviors in learning methods in lectures.

Based on the results of research conducted by Ikram and Kamil (6) on the effectiveness of the application of the PBL method on learning achievement, in general, it was found that almost $2 / 3 \quad(62.5 \%)$ of respondents resolved problems with group discussions. This method supports students when answering and responding to questions, communicating following the activities to analyze problems using the 7 th jumps method. The ability to analyze and solve these problems is an essential competency for a leader to have.

Based on the statement above, the SCL learning method can explain how critical leadership skills are for a student. So that later competent new leaders can be created in the future (3).

The purpose of this study was to determine the correlation between the application of the SCL learning method (Small Group Discussion and Role Play and Simulation) with the development of student leadership behavior at the Faculty of Nursing, Universitas Syiah Kuala (FON-USK), Banda Aceh.

The development of the world, especially Indonesia and the province of Aceh, continues to improve when the ASEAN Economic Community (AEC) era was launched at the end of 2015. Requires good competent graduates who function as leaders to lead an organization and provide solutions to various problems, especially in the nursing profession. Therefore, higher nursing education institutions are expected to be able to produce reliable nurses beyond the needs of society and the development of science and technology and are also required to be able to produce professional leaders as a long-term and sustainable process of change that has an impact on the development of the nursing profession (7).

\section{MATERIALS AND METHODS}

The research type is quantitative research using a cross-sectional design carried out on the end of May 2018 at FON-USK. The sample in this study was 382 students of Regular A with purposive sampling technique.

The data measuring instrument in this study, the researcher used a questionnaire compiled by the researcher. The questionnaire used consists of three parts, namely: demographic data, Questionnaire for Application of the SCL Method, which is compiled based on the Learning Method based on the Directorate General of Higher Education (8), with four answer options: Strongly Agree = 4 , Agree $=3$, No Agree $=2$, and Strongly Disagree $=1$ for positive statements, while for negative statements the value applies vice versa. The Student Leadership Behavior Development Questionnaire was compiled by referring to theory X and theory Y McGregor (2002) quoted by Weiss and Tappen (9), with four answer choices, namely, Always $=4$, Often $=3$, Rarely $=2$, and Never $=1$.

The following steps process the data: editing, coding, transferring, and tabulating. Before the data was collected, the instrument was tested on 20 students of the Faculty of Medicine, Universitas Syiah Kuala. The reliability test in this study was carried out using Cronbach's Alpha Test with a value of 0.967 so that the statements contained in the questionnaire were considered reliable (10).

The research was conducted after receiving a letter of passing the ethical test from the FONUSK Ethics Committee, which aims to protect and ensure the confidentiality of respondents. Pearson Product Moment analysis is used to determine the interaction of two variables that are thought to be related or correlated.

\section{RESULTS}

Based on the results of research that has been conducted on 382 respondents, the following results were obtained:

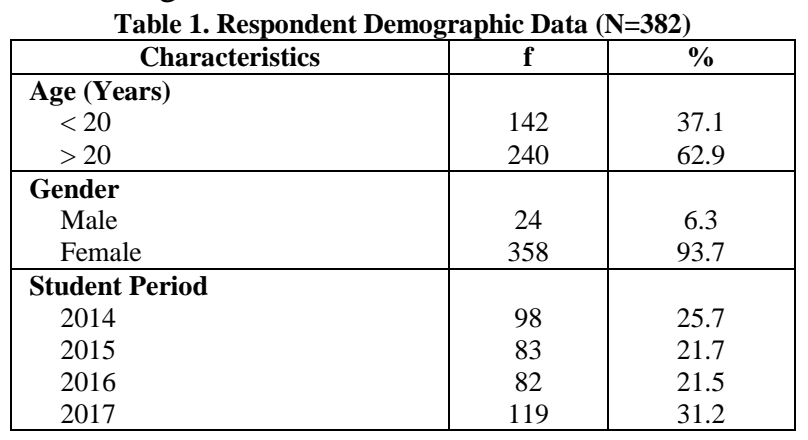


Based on Table 1 above, it can be concluded that the age of the most respondents is, it can be concluded that the age of the most respondents is $>20$ years as many as 240 $(62.9 \%)$ respondents, the dominant gender is female, namely $358(93.7 \%)$ respondents, and the most significant student period is the 2017 class, which is 119 respondents (31) $2 \%$ ).

Table 2. Correlation of Small Group Discussion (SGD) with Student Leadership Behavior FON-USK

\begin{tabular}{|c|c|c|c|c|}
\hline Variable & $\overline{\boldsymbol{x}}$ & SD & p-value & r \\
\hline Small-Group Discussion & 18.39 & 1.981 & 0,000 & 0.263 \\
\cline { 1 - 3 } Leadership Behavior & 39.68 & 4.521 & & \\
\hline
\end{tabular}

For the SGD learning method, based on Table 2, the results of the Pearson Product Moment obtained $p$-value $=0.000 ; \alpha=0.01$. It can be concluded that Ho is rejected, which means that there is a relationship between the application of the SGD learning method and the development of student leadership behavior. Pearson correlation coefficient value $(r=0.263)$, it can be assumed that there is a "Low/weak" correlation between SGD and leadership behavior of FON-USK Banda Aceh students.

Table 3. Correlation of Role Play and Simulation (RPS) with student leadership behavior FON-USK

\begin{tabular}{|c|c|l|c|c|}
\hline Variable & $\overline{\boldsymbol{x}}$ & SD & p-value & r \\
\hline Role Play and Simulation & 14.49 & 2.240 & 0,018 & 0.121 \\
\hline Leadership Behavior & 39.68 & 4.521 & & \\
\hline
\end{tabular}

Then, the RPS learning methods, based on Table 3, the results of the Pearson Product Moment obtained $\mathrm{p}$-value $=0.018, \alpha=0.01$. It can be concluded that Ho is rejected, which means that there is a relationship between applying the RPS learning method and the development of student leadership behavior. Pearson correlation coefficient value $(r=0.121)$, it can be assumed that there is a "very low" correlation between RPS and leadership behavior of FON-USK Banda Aceh students.

\section{DISCUSSION}

The Correlation between the Application of the Small Group Discussion (SGD) Method with the Leadership Behavior of FON Students

Based on Table 2, there is a relationship between the application of the SGD learning method with the development of leadership behavior of FON-USK Banda Aceh students. Researchers assume this correlation can be caused because the group discussion method will create student leadership skills such as critical thinking to solve problems, be responsible, public speaking, and respect others. This leadership behavior will continue to be honed and developed along with the students' habit of conducting tutorial discussions.

This result is supported by Komaruddin (11) research, which states that leadership skills can be improved through discussions in small groups (buzz-group). The pre-test results showed that the students' lowest leadership skill scale score was 80 with low criteria. After the auction, the student's score increased to 121 with moderate criteria. Thus, it can be concluded that the small group discussion (buzz-group) or SGD conducted at FON-USK can improve students' leadership skills.

Some view leadership as one of management's many functions; others maintain that leadership requires more complex skills than management and that management is only one leadership role (12). Influential leaders choose to act with caution. Important behaviors in leadership are setting specific goals, thinking critically, solving problems, respecting people, communicating skillfully, communicating a vision for the future, and developing oneself and others (9). This statement is in line with McGregor's theory of behavior $\mathrm{X}$ and $\mathrm{Y}$ which states that every human being is an individual life that interacts with the world of other individuals. What happens to that person is a result of the behavior of others. The attitudes and emotions of others affect the person (13).

The study finding itself shows the correlation coefficient value of 0.263 , which means a low/weak correlation between the SGD learning method and student leadership behavior. It may be due to the lack of students who participate actively and productively in each discussion group. It can be proved by the number of 382 respondents, as many as 124 (32.5\%) respondents chose the answer "rarely" to participate actively, and 192 (50.3\%) respondents chose the answer "agree" to the statement of a less productive attitude in the discussion. So, although the SGD learning method is very well applied in learning and affects student leadership, there are still many students who have not maximized the use of this learning method.

The Relationship between the Application of the Role Playing and Simulation (RPS) Method with the Leadership Behavior of FON Students

Based on Table 3, there is a relationship in the application of the RPS learning method 
with the development of leadership behavior of FON-USK Banda Aceh students. The correlation between variables seemly caused by the RPS method seems quite fascinating, fun, and makes students want to interact in it. Students' skills and abilities, such as responsibility and leadership in learning, partners in the teaching and learning process, and problem-solving, will develop creatively through this learning method. Compared to developing it using traditional teaching techniques.

The statement above is supported by research conducted by Marita et al. (14), which states that the students' habits of mind score after using the role-playing (RP) method increased by 5 points (Pre-RP 71.8 and Post-RP 76.8). These abilities include thinking creatively, critically, and self-regulation with a p-value of $0.000<(0.025)$. It can be concluded that the role-playing method affects the habits of mind of physiotherapy students.

Craciun (15) also stated that the roleplaying method would increase the ability of students to be more active in problem-solving involvement in groups (leadership and communication skills), more active, and confidence. In addition, role-playing is currently widely used in various disciplines, including health sciences (16). The political science faculty found that role-playing simulations have the complex power to create a process of political dynamics in the classroom, which allows students to examine motivation, behavior, reason, and institutional interactions. Role-playing is also used to facilitate understanding complex concepts such as physics, chemistry, and other sciences (17).

However, the correlation coefficient value between the RPS learning method and student leadership behavior in this study is still very low $(r=0.121)$. Researchers assume that this happens because many students still do not like the application of the RPS learning method. This assumption can be shown by as many as 197 (51.6\%) respondents choosing the answer "do not like" learning with the RPS method because it makes them feel ashamed to play a role. Furthermore, as many as 188 (49.2\%) respondents chose the answer "agree" that learning with the RPS method is tedious. Although there are many exciting and fun things with the RPS learning method and the influence on student leadership development, there are still many students who do not maximize the function of this method in tutorial learning.

\section{CONCLUSION}

Based on the results of research and discussions that have been carried out, it can be concluded that there is a relationship between the application of various learning methods including:

1. Small Group Discussion $(\overline{\boldsymbol{x}}=18.39$; $\mathrm{p}$ value $=0.000 ; r=0.263)$,

2. Role Playing and Simulation $(\overline{\boldsymbol{x}}=14.49 ; \mathrm{p}-$ value $=0.018 ; \mathrm{r}=0.121$ ),

on the development of student leadership behavior at the Faculty of Nursing, Universitas Syiah Kuala. To the management of faculties, departments and study programs, it is recommended that they continue to develop innovative learning methods based on the Indonesian Curriculum Qualification Framework so that they can improve leadership abilities and the process of achieving graduates who are able to compete in the national and international world of work.

\section{Acknowledgement: None}

\section{Conflict of Interest: None}

\section{Source of Funding: None}

\section{REFERENCES}

1. Sudjarwadi. College Curriculum. Yogyakarta: Universitas Gajah Mada; 2010.

2. Sailah I. Pengembangan soft skills di perguruan tinggi. Tim Kerja Pengembangan Soft Skills, editor. Jakarta: Direktorat Jenderal Pendidikan Tinggi, Departemen Pendidikan Nasional RI; 2008.

3. FON-USK. Form of Program Nursing Science Study Form, Syiah University Kuala, Banda Aceh. Banda Aceh; 2015.

4. Robbins SP, Judge TA. Essentials of Organization Behavior. Fourthtent. Boston: Pearson Education; 2016.

5. Putra IS, Pratiwi A. Sukses dengan soft skills. Bandung: Direktorat Pendidikan ITB; 2005

6. Ikram A, Kamil H. PBL Seven Jumps Method With Successful Learning of Students of the Faculty of Nursing, Syiah Kuala University. 2016;1(1):1-8. 
7. Ali HZ. Fundamentals of leadership in nursing. Jakarta: CV. Trans Info Media; 2010.

8. Ditjen Dikti. Higher Education Competency-Based Curriculum Guide. Jakarta: Direktorat Jenderal Pendidikan Tinggi; 2014.

9. Weiss S, Tappen R. Essentials of Nursing Leadership and Management. Sixth. Klim M, editor. Philadelphia: F. A. Davis Company; 2015.

10. Burns N, Grove SK. The Practice of Nursing Research: Conduct, Critique, and Utilization. 5th ed. St. Louis, Missouri: Elsevier Saunders; 2005.

11. Komaruddin R. Improve the leadership skill of students through buzz-group in SMA Negeri 1 Pakem. J Bimbing dan Konseling. 2016;1(5):1-11.

12. Marquis BL, Huston CJ. Leadership roles and management functions in nursing: theory and application. Ninth. Philadelphia: Wolters Kluwer Health; 2017.

13. Swansburg RC, Swansburg RJ. Introduction to management and leadership for nurse managers. Third. Canada: Jones and Bartlett Publishers; 2002.

14. Marita R, Amanati S, Kuswardani. The effect of the role-playing method on the habits of mind ability of physiotherapy students. In: Seminar Nasional dan Call for Paper 2017. 2017. p. 453-62.

15. Craciun D. Role playing as creative method in science education. J Sci Arts. 2010;12(1):175-82.

16. Manzoor I, Lam P, Yu H. Medical student perspective about role-plays as a teaching strategy in community medicine. J Coll Physicians Surg Pakistan. 2012;22(4):2225.

17. Paudi ZI. The application of the roleplaying method in learning physics to improve student learning outcomes. Indones J Sci Educ. 2019;7(2):111-20.

How to cite this article: Putra A, Maulana R, Nurhasanah et.al. Application of SCL learning methods and student leadership behavior: a correlational study. Gal Int J Health Sci Res. 2021; 6(4): 1-5. DOI: https://doi.org/10.52403 /gijhsr.20211001 